\title{
Peningkatan Kreativitas Mahasiswa PGSD dalam Mendesain Media Pembelajaran
}

\author{
Hotimah \\ Prodi Pendidikan Guru Sekolah Dasar, Fakultas Ilmu Pendidikan, Universitas Negeri Makassar \\ hotimah@unm.ac.id
}

\begin{abstract}
ABSTRAK
Kreativitas merupakan salah satu kunci kesuksesan seseorang. Sebagai calon pendidik, mahasiswa harus memiliki kreativitas, salah satunya kreativitas dalam mendesain media pembelajaran. Media pembelajaran yang dirancang sendiri oleh guru, diharapkan akan lebih efektif dan efesien dalam memprasaranai proses pembelajaran sehingga terjadi pembelajaran yang bermakna dan mendukung tercapainya tujuan pembelajaran. Penelitian PTK melalui penerapan metode pembelajaran Project Based Learning (PjBL) ini, mahasiswa PGSD mampu meningkatkan kreativitasnya dalam mendesain media pembelajaran bagi siswa SD. Hal ini terlihat dari data hasil obervasi kreativitas mahasiswa yang mengalami peningkatan, dimana pada pra siklus sebesar $51,2 \%$, pada siklus I meningkat menjadi $63,4 \%$, dan pada siklus II meningkat menjadi $74,1 \%$. Pada siklus I mahasiswa menghasilkan media pembelajaran yang berupa media konvensional. Sedangkan pada siklus II proyek yang dikerjakan mahasiswa yaitu media pembelajaran digital (video). Adapun kualitas media pembelajaran yang dihasilkan mendapakan kategori layak (baik) dengan rerata skor 3,34. Peningkatan kreativitas mahasiswa PGSD dalam mendesain media pembelajaran berhasil karena dengan penerapan metode pembelajaran Project Based Learning (PjBL) mahasiswa dituntut untuk memecahkan permasalahan terkait pentingnya mendesain media pembelajaran yang mendukung tercapainya tujuan pembelajaran, mahasiswa terlibat aktif, terlihat senang, mampu bekerjasama dalam tim, serta mampu memberikan ide maupun pendapat selama proses pembelajaran.
\end{abstract}

Kata kunci: kreativitas, media pembelajaran, project based learning

\section{ABSTRACT}

Creativity is one of the keys to get success. As prospective educators, students must have creativity, which one is creativity in designing learning media. Learning media that designed by teacher self are expected to be more effective and efficient in parading the learning process so that meaningful learning takes place, and supports the achievement of learning objectives. Through the implementation of Project Based Learning (PjBL) learning method, PGSD students are able to increase their creativity in designing learning media for elementary students. This can be seen from the data on the creativity results of students who experienced an increase, where in the pre cycle is $51.2 \%$, in the first cycle increased to $63.4 \%$, and in the second cycle increased to $74.1 \%$. In the first cycle students produce learning media in the form of conventional media. Whereas in the second cycle, the projects undertaken by students are digital learning media (video). The quality of the learning media produced earned a decent (good) category with a mean score of 3.34. Increased creativity of PGSD students in designing learning media is successful because by applying the Project Based Learning (PjBL) learning method, students are required to solve problems related to the importance of designing learning media that supports the achievement of learning objectives, students are actively involved, look happy, able to work in team, and are able provide ideas and opinions during the learning process.

Keyword: creativity, instructional media,

\section{PENDAHULUAN}

Salah satu yang menjadi faktor

kesuksesan seseorang adalah kemampuannya secara kreatif dalam menyelesaikan masalah. Seorang yang kreatif akan mampu melihat suatu masalah dari sudut pandang yang berbeda. Dari sudut pandang yang berbeda inilah, maka individu tersebut akan mampu memperoleh alternatif solusi untuk menyelesaikan masalah tersebut. Seseorang yang kreatif tentu juga dapat 
meningkatkan kualitas hidup, mendesain sesuatu, mengkreasi perubahan, serta mampu meningkatkan efisiensi dan efektivitas suatu sistem.

Agar mampu bersaing dengan negara maju, Indonesia sebagai negara berkembang, membutuhkan sumber daya manusia yang cerdas, cakap, kreatif, beriman, dan berakhlak mulia sesuai dengan tujuan pendidikan nasional. Sesuai dengan tujuan Pendidikan nasional, salah satu kemampuan peserta didik yang perlu dikembangkan adalah kreativitas. Kreativitas merupakan suatu kemampuan berpikir divergen atau cara memecahkan suatu permasalahan dengan menggunakan berbagai macam alternatif jawaban terhadap persoalan yang sama benarnya (Ardianti, Pratiwi, \& Kanzunnudin., 2017). Kreativitas adalah kegiatan yang mendatangkan hasil yang sifatnya baru (inovatif) atau belum ada sebelumnya, segar, menarik, aneh dan mengejutkan, berguna dan dapat dimengerti (Purwanto, 2011).

Sebagian besar definisi ide kreatif terdiri dari tiga komponen. Pertama, ide-ide kreatif harus mewakili sesuatu yang berbeda, baru, atau inovatif. Kedua, ide-ide kreatif sangat tinggi kualitas. Ketiga, ide-ide kreatif juga harus sesuai dengan tugas yang dihadapi atau definisi ulang dari tugas itu. Dengan demikian, respons kreatif itu baru, baik, dan relevan. (Kaufman \& Sternberg, 2011)

Menurut Hurlock (M. A. Titu, 2015) kreativitas meliputi baik ciri-ciri aptitude seperti kelancaran (fluency), keluwesan (flexibility), dan keaslian (originality) dalam pemikiran, maupun ciri-ciri non-aptitude, seperti rasa ingin tahu, senang mengajukan pertanyaan dan selalu ingin mencari pengalamanpengalaman baru, serta kreativitas adalah kemampuan untuk mengkombinasikan, memecahkan atau menjawab masalah, dan cerminan kemampuan operasional anak kreatif.

Adapun penjelasan lebih lanjut dari ciriciri kreativitas yaitu: (1) Kelancaran berpikir (fluency of thinkin), yaitu kemampuan untuk menghasilkan banyak ide yang keluar dari pemikiran seseorang secara cepat. Dalam kelancaran berpikir, yang ditekankan adalah kuantitas (bukan kualitas); (2) Keluwesan berpikir (flexibility), yaitu kemampuan untuk memproduksi sejumlah ide, jawaban atau pertanyaan yang bervariasi, dapat melihat suatu masalah dari sudut pandang yang berbeda, mencari alternatif atau arah yang berbeda, serta mampu menggunakan bermacam-macam pendekatan atau cara pemikiran. Orang yang kreatif adalah orang yang luwes dalam berpikir.
Mereka dengan mudah dapat meninggalkan cara berpikir lama dan menggantikannya dengan cara berpikir yang baru. (3) Elaborasi (elaboration), yaitu kemampuan dalam mengembangkan gagasan dan menambahkan atau memperinci detail dari suatu objek, gagasan atau situasi sehingga menjadi lebih menarik; (4) Originalitas (originality), yaitu kemampuan untuk mencetuskan gagasan unik atau kemampuan untuk mencetuskan gagasan asli (A. M. Titu, 2015).

Selain ketiga ciri kreativitas yang dikemukakan oleh Hurlock di atas, Boden et al (Mahmudi, 2008) menambahkan komponen-ciri kreativitas dengan faktor kebermanfaatan (useful). Menurut Boden et al, suatu produk atau hasil karya dikategorikan kreatif apabila produk atau karya tersebut memiliki manfaat (useful). Ia mengatakan bahwa walaupun suatu karya atau produk dikategorikan baru, namun apabila tidak bermanfaat atau bahkan merugikan, maka hasil karya atau produk itu tidak bermakna dan oleh karenanya tidak dapat dikategorikan kreatif.

Banyak ahli yang menekankan kreativitas pada aspek kemampuan yang merujuk pada kemampuan kognitif. Sedangkan kemampuan kogntif sering diasosiasikan dengan intelegensi atau kecerdasan. Pandangan seperti ini tentu saja salah. Menurut Hayes (Nakin, 2003), kecerdasan bukan syarat mutlak dari kreativitas. Kreativitas juga perlu didukung oleh tumbuhnya motivasi yang tinggi. Dengan motivasi yang tinggi, seseorang akan terdorong untuk mencurahkan perhatian pada aktivitas yang dilakukan sehingga ia akan lebih berpengetahuan dalam bidangnya. Pengetahuan inilah yang memungkinkan seseorang tersebut untuk menjadi individu kreatif. Pendapat lain yang menekankan intelegensi bukan syarat mutlak tumbuhnya kreativitas juga di kemukakan oleh Haylock (1997). Haylock mengaitkan kreativitas dengan kedalaman pengetahuan, wawasan, serta fleksibilitas. Ia sering mengasosiasikan kreativitas dengan periode kerja panjang yang rentan terhadap pengaruh-pengaruh eksperimental, termasuk didalamnya pembelajaran. Pandangan Haylock ini memberikan dasar yang kokoh untuk mengembangkan usaha-usaha edukatif untuk mengembangkan kreativitas peserta didik melalui aktivitas pembelajaran yang terencana dengan baik (Haylock, 1997). Dengan demikian bisa disimpulkan bahwa biasanya individu kreatif adalah orang individu yang cerdas, tetapi individu yang cerdas belum tentu kreatif.

$$
\text { Ada beberapa faktor yang }
$$$$
\text { mempengaruhi perkembangan kreativitas }
$$ 
seseorang, yaitu faktor internal dan faktor eksternal. Faktor internal yang berasal dari dalam diri individu yang dimaksud adalah motivasi, intelegensi, dan jenis kelamin. Sedangkan faktor eksternal diantaranya adalah lingkungan desa atau kota, ukuran keluarga, kondisi sosial ekonomi (Fatmawiyati, 2018).

Pada dasarnya, setiap orang yang dilahirkan memiliki potensi kreatif dengan level yang berbeda-beda. Kreativitas dapat diidentifikasi dan dipupuk melalui pendidikan yang tepat (Munandar, 1997). Untuk dapat memupuk kreativitas, maka dalam pembelajaran pendidik harus mengenal strategi-strategi pembelajaran yang mendorong peserta didiknya dalam mengembangkan kemampuan kreativitasnya.

Salah satu cara untuk melatih dan mengembangkan kreativitas peserta didik adalah dengan melaksanakan model pembelajaran Project Base Learning. Project Based Learning (pembelajaran berbasis proyek) merupakan sebuah model pembelajaran yang sudah banyak dikembangkan di negara-negara maju. Project Based Learning merupakan pendekatan pembelajaran yang memberikan kebebasan kepada peserta didik untuk merencanakan aktivitas belajar, melaksanakan proyek secara kolaboratif, dan pada akhirnya menghasilkan produk kerja yang dapat dipresentasikan kepada orang lain. Project Based Learning merupakan kegiatan pembelajaran yang dapat mengaktifkan peserta didik serta dapat mengembangkan potensi yang dimiliki oleh setiap peserta didik (Ardianti, Pratiwi, \& Kanzunnudin, 2017).

Project Based Learning (PjBL) memusatkan pada masalah kehidupan yang bermakna bagi peserta didik. Dalam model pembelajaran ini, peran pendidik adalah menyajikan masalah, mengajukan pertanyaan dan memfasilitasi peserta didik dalam merancang sebuah proyek yang akan mereka lakukan. Dan ini akan menambah kreativitas peserta didik dalam merancangkan sebuah proyek yang kemudian akan mereka kerjakan dalam waktu yang sudah pendidik sediakan sesuai dengan konsep yang diajarkan (M. A. Titu, 2015).

Keuntungan model pembelajaran Project Based Learning adalah sebagai berikut: 1). Meningkatkan motivasi belajar peserta didik; 2). Meningkatkan kemampuan pemecahan masalah; 3). Meningkatkan kolaborasi; 4). Meningkatkan keterampilan mengelola sumber. Sedangkan kelemahan dari pembelajaran berbasis proyek ini antara lain: 1). Banyak permasalahan yang tidak terpisahkan dengan masalah kedisiplinan, untuk itu disarankan mengajarkan dengan cara melatih dan memfasilitasi peserta didik dalam menghadapi masalah; 2). Memerlukan banyak waktu yang harus disediakan untuk menyelesaikan masalah; 3). Membutuhkan biaya yang cukup banyak; 4). Banyak pendidik yang merasa nyaman dengan kelas tradisional, di mana pendidik memegang peran utama di kelas; 5). Banyak peralatan yang harus disediakan (Titu, 2015: 179-180).

Dalam pembelajaran Project Based Learning, peserta didik terdorong lebih aktif dalam belajar. Pendidik hanya sebagai fasilitator, mengevaluasi produk hasil kerja peserta didik yang ditampikan dalam hasil proyek yang dikerjakan, sehingga menghasilkan produk nyata yang dapat mendorong kreativitas peserta didik dalam mendesain media pembelajaran.

Kemampuan guru atau calon guru, dalam penelitian ini adalah mahasiswa program studi PGSD, untuk dapat mendesain media pembelajaran adalah sesuatu yang penting. Media pembelajaran adalah komponen komunikasi yang berfungsi sebagai perantara atau pembawa pesan dari pengirim ke penerima (Rohani, 2017). Media pembelajaran adalah segala sesuatu yang dapat digunakan untuk menyalurkan pesan atau isi pelajaran, merangsang pikiran, perasan, perhatian dan kemampuan peserta didik.

Tugas guru dalam proses pembelajaran tidak hanya sebagai penyampai informasi kepada peserta didik. Guru juga harus memiliki kemampuan untuk memahami peserta didik dengan berbagai perbedaannya agar mampu membantu mereka dalam menghadapi kesulitan belajar. Oleh karenanya, guru dituntut untuk mampu menyediakan dan menggunakan berbagai media pembelajaran yang sesuai dengan materi. Penggunaan media yang tepat akan turut menentukan tingkat keberhasilan proses pembelajaran.

Media sebagai alat bantu dalam proses pembelajaran dapat membantu tugas guru dalam menyampaikan pesan-pesan dari materi ajar kepada anak didik. Media pendidikan merupakan sarana dan prasarana untuk menunjang terlaksananya proses pembelajaran. Untuk itu keberadaan media pembelajaran tidak dapat diabaikan begitu saja dalam proses pembelajaran hal ini dikarenakan tanpa adanya media pembelajaran, pelaksanaan proses pembelajaran tidak akan berjalan dengan baik (Abdullah, 2017).

Arsyad (dalam Divan et al., 2020) ada 5 
kriteria dalam pemilihan media pembelajaran, yaitu, 1) sesuai dengan tujuan yang ingin dicapai, yakni mampu mengukur tercapainya domain kognitif, afektif, dan psikomotorik. Media pembelajaran tidak hanya mampu mempengaruhi aspek intelegensi saja, namun juga mampu mempengaruhi aspek lain yaitu sikap dan perbuatan.; 2) praktis, luwes, dan bertahan. Media pembelajaran harus efektif. Media tidak harus rumit, mahal, dan selalu berbasis teknologi. Media yang sederhana dan mudah dalam penggunaannya, harga terjangkau, dapat digunakan secara terus-menerus, merupakan salah satu pertimbangan utama dalam memilih media pembelajaran.; 3) Mampu dan terampil menggunakan. Guru harus mampu menggunakan media apapun yang dipilih. Keterampilan dalam menggunakan media pembelajaran akan menentukan manfaat dan nilai dari media pembelajaran tersebut.; 4) Keadaan peserta didik. Agar dapat membantu siswa dalam memahami materi pembelajaran, media pembelajaran yang dipilih harus disesuaikan dengan keadaan peserta didik, baik keadaan psikologis, filosofis, maupun sosiologis siswa.; 5) Ketersediaan. Agar dapat digunakan untuk mencapai tujuan pembelajaran, tentu saja media yang dipilih harus tersedia. Kelima kriteria ini merupakan komponen penting dalam mendesain media pembelajaran.

Agar mahasiswa mampu mendesain media pembelajaran dengan kreatif, maka langkah pembelajaran Project Based Learning yang dilakukan adalah sebagai berikut:

1. Planning, dalam pelaksanaannya meliputi persiapan proyek dan perencanaan proyek. Pada tahap ini, peserta didik dihadapkan pada masalah rill di lapangan, dan mendorong mereka untuk mengidentifikasi masalah tersebut. Selanjutnya peserta didik diminta menemukan alternatif pemecahan masalah yang ditemukan di lapangan serta mendesain model pemecahan masalah.

2. Creating, yaitu pelaksanaan proyek yang memberikan kesempatan seluas-luasnya pada peserta didik untuk merancang dan melakukan laporan investigasi serta mempresentasikan produk.

3. Processing, aktivitas pada tahap ini meliputi presentasi proyek dan evaluasi proyek. Peserta didik mengkomunikasikan secara aktual project atau temuan dari investigasi kelompok termasuk refleksi dan tindak lanjut proyek. Pada tahap ini juga dilakukan evaluasi.

Dari pemaparan di atas maka perlu dilakukan penelitian, bagaimana pelaksanaan metode pembelajaran Project Based Learning mampu meningkatkan kreativitas mahasiswa PGSD dalam mendesain media pembelajaran yang berkualitas.

\section{METODE PENELITIAN}

Jenis penelitian ini merupakan penelitian tindakan kelas. Menurut Suharsimi Arikunto (2014: 3) penelitian tindakan kelas merupakan suatu pencermatan terhadap kegiatan belajar berupa sebuah tindakan, yang sengaja dimunculkan dan terjadi dalam sebuah kelas secara bersama. Dalam penelitian ini variabel yang diteliti adalah peningkatan kreativitas mahasiswa program studi PGSD dalam mendesain media pembelajaran yang berkualitas bagi siswa SD melalui model pembelajaran Project Based Learning.

Penelitian dilaksanakan pada bulan Agustus sampai dengan bulan November 2019, yang bertempat di Program Studi Pendidikan Guru Sekolah Dasar (PGSD) Fakultas Ilmu Pendidikan Universitas Negeri Makassar, yang beralamat di Jalan Tamalate I, Tidung, Makassar, Sulawesi Selatan. Adapun subyek penelitian ini adalah mahasiswa program studi PGSD Fakultas Ilmu Pendidikan Universitas Negeri Makassar semester IV pada tahun akademik 2019-2020. Adapun jumlah subyek penelitian berjumlah 80 mahasiswa.

Adapun tahapan dalam penelitian ini yaitu: (1) perencanaan, (2) pelaksanaan, (3) pengamatan, dan (4) refleksi. Sebelum tahapantahapan tersebut dilaksanakan, terlebih dahulu diawali oleh suatu tahapan Pra PTK. Prosedur dan langkah-langkah yang digunakan dalam melaksanakan penelitian ini mengikuti model spiral yang dikembangkan oleh Kemmis dan Mc Taggart. Menurut Kusumah dan Dwitagama (2010: 21) "Model Kemmis dan Mc Taggart pada hakekatnya berupa perangkat-perangkat atau untaian-untaian dengan satu perangkat terdiri dari 4 komponen yaitu: rencana tindakan (planning), tindakan (acting), pengamatan (observing) dan refleksi (reflecting). Keempat komponen yang berupa untaian tersebut dipandang sebagai satu siklus". Menurut Arikunto, dkk (2007: 104) "Apabila satu siklus belum menunjukkan tanda-tanda perubahan ke arah perbaikan (peningkatan mutu), kegiatan riset dilanjutkan pada siklus kedua dan seterusnya, sampai peneliti merasa puas." Menurut Sulipan (2008: 17), penelitian tindakan kelas (PTK) harus dilakukan sekurangkurangnya dalam dua siklus tindakan yang berurutan; informasi dari siklus yang terdahulu sangat menentukan bentuk siklus berikutnya. 
Oleh karena itu siklus yang kedua, ketiga dan seterusnya tidak dapat dirancang sebelum siklus pertama terjadi. Langkah-langkah penelitian untuk setiap siklus dalam penelitian ini dapat diilustrasikan dalam siklus sebagai berikut:

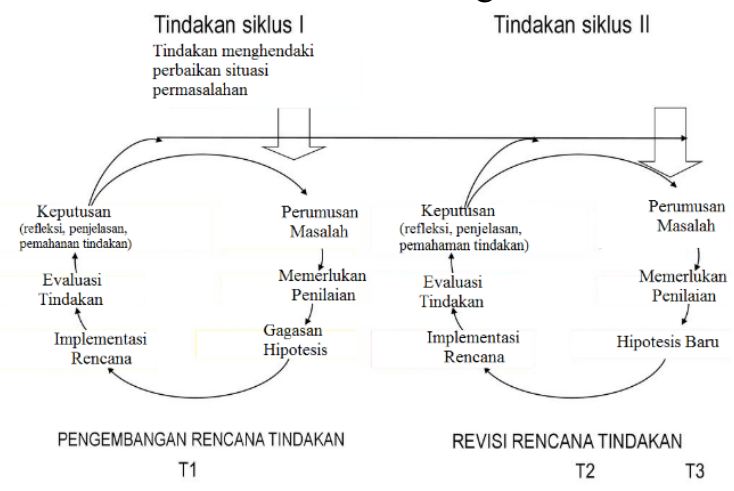

Gambar 1. Desain Penelitian Tindakan Kelas (Hopkins, 2008: 53)

Dalam penelitian ini, teknik pengumpulan data yang dipakai adalah observasi, catatan lapangan dan dokumentasi. Lembar instrumen yang disiapkan adalah lembar kreativitas yang terdiri dari 5 komponen yaitu kelancaran berpikir (fluency of thinkin), keluwesan berpikir (flexibility), elaborasi (elaboration), originalitas (originality), dan kebermanfaatan (useful). Instrumen ini diisi oleh peneliti dan kolaborator dengan memberikan tanda check list $(\sqrt{ })$ pada setiap indikator yang sesuai dengan tingkat kreativitas yang muncul pada mahasiswa. Selain instrumen kreativitas, peneliti juga menyiapkan instrumen kualitas media pembelajaran yang dihasilkan oleh mahasiswa PGSD FIP UNM. Dimana instrumen ini terdiri dari 5 komponen (ciri) kualitas media pembelajaran (sesuai dengan tujuan yang ingin dicapai; praktis, luwes, dan bertahan; mampu dan terampil menggunakan, keadaan peserta didik, dan ketersediaan).

Adapun analisis data dalam Penelitian Tindakan Kelas (PTK) ini dimulai sejak awal sampai berakhirnya pengumpulan data. Datadata dari hasil penelitian di lapangan diolah dan dianalisis secara kualitatif maupun kuantitatif. Teknik analisis kualitatif mengacu pada model analisis Miles dan Huberman (Soegiyono, 2010: 336) yang dilakukan dalam tiga komponen yaitu reduksi data, penyajian data dan penarikan kesimpulan dan verifikasi. Adapun skema dari pemeriksaan analisis data yang digunakan dapat dilihat dalam gambar berikut:

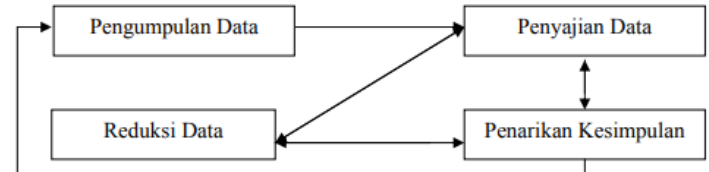

Gambar 2. Skema analisis data

Reduksi data merupakan kegiatan merangkum, memilih hal-hal pokok, memfokuskan hal-hal penting, mencari tema dan polanya, serta membuang hal yang tidak perlu. Reduksi data dilakukan melalui pemilihan data, penyederhanaan data, serta transformasi data kasar dari hasil catatan lapangan. Penyajian data adalah teknik peyajian data yang terorganisir, tersusun dalam pola hubungan, sehingga akan semakin mudah dipahami. Penarikan kesimpulan merupakan pengambilan keputusan dengan didukung bukti yang valid dan konsisten.

Sedangkan analisis data kuantitatif dianalisis menggunakan statistik deskriptif kualitatif. Teknik analisis data menggunakan statistik deskriptif yang kemudian dikonversikan menjadi data kualitatif skala 5 (Skala Likert). Kualitas media pembelajaran yang digambarkan oleh rerata $(\bar{x})$. Nilai rerata yang diperoleh dikategorikan dalam kualitas pada skala 1-5 dengan menggunakan batas yang membagi skala tersebut dalam lima bagian yang sama dengan acuan rumus sebagai berikut:

Table 1. Kriteria Penilaian Kualitas Media Pembelajaran

\begin{tabular}{|c|c|c|}
\hline Nilai & Kategori & Rentang Skor \\
\hline 5 & Sangat layak & $\bar{X}_{l}+1,8 S d_{i}<X$ \\
\hline 4 & Layak & $\bar{X}_{l}+0,6 S d_{i}<X \leq \bar{X}_{l}+1,8 S d$ \\
\hline 3 & Cukup & $\bar{X}_{l}-0,6 S d_{i}<X \leq \bar{X}_{l}+0,6 S d$ \\
\hline 2 & Kurang & $\bar{X}_{L}-1,8 S d_{i}<X \leq \bar{X}_{l}-0,6 S d$ \\
\hline 1 & Sangat kurang & $X \leq \bar{X}_{l}-1,8 S d_{i}$ \\
\hline \multicolumn{3}{|c|}{ Ketentuan: } \\
\hline $\bar{X}_{l}$ & \multicolumn{2}{|c|}{$\begin{array}{l}\text { : Rerata skor ideal } \\
1 / 2(\text { skor maksimal + skor minimal) }\end{array}$} \\
\hline$S d_{i}$ & \multicolumn{2}{|c|}{ 1/6 (skor maksimal - skor minimal) } \\
\hline
\end{tabular}

(Hotimah \& Muhtadi, 2017)

\section{HASIL \& PEMBAHASAN}

Data yang dikumpulkan adalah data peningkatan kreativitas mahasiswa PGSD yang diperoleh dengan teknik observasi terhadap 5 indikator ciri kreativitas, dan 5 kriteria media pembelajaran. Adapun tindakan yang dilakukan dalam penelitian ini terdiri 2 siklus dengan gambaran yaitu sebagai berikut: 


\section{Pra Siklus}

Sebelum pelaksanaan tindakan kelas yaitu penerapan model pembelajaran Project Based Learning (PjBL), terlebih dahulu peneliti melakukan pengamatan terhadap mahasiswa program studi Pendidikan Guru Sekolah Dasar (PGSD) Fakultas Ilmu Pendidikan Universitas Negeri Makassar. Pengamatan yang merupakan kegiatan pra siklus ini dilakukan di awal perkuliahan yaitu pada bulan Agustus 2019.

Dari hasil pengamatan pra siklus ini peneliti menemukan bahwa kreativitas mahasiswa program studi PGSD masih rendah, dimana kelancaran berpikir mahasiswa dalam menyampaikan ide-ide masih sangat kurang. Dan hal ini didukung dengan kurangnya penyampaian jawaban yang kurang variatif dari mahasiswa ketika peneliti mengajukan beberapa pertanyaan. Mahasiswa juga cenderung pasif dalam mengikuti perkuliahan. Mereka cenderung duduk dan hanya mendengarkan penjelasan dari peneliti. Dari hasil data observasi menunjukkan bahwa kreativitas awal mahasiswa prodi PGSD FIP UNM sebelum dilakukan metode pembelajaran Project Based Learning (PjBL) secara keseluruhan adalah 51,2\%.

\section{Siklus I}

Tindakan siklus 1 mulai dilaksanakan pada bulan September sampai pertengahan bulan Oktober 2019 (6 kali pertemuan). Pada awal siklus, peneliti menghadapkan mahasiswa pada adanya masalah pentingnya media pembelajaran dalam mendukung tercapainya tujuan pembelajaran di Sekolah Dasar. Setelah menghadapkan mahasiswa pada masalah ril di lapangan, peneliti kemudian mengintruksikan mahasiswa untuk membentuk beberapa kelompok kecil, dimana setiap kelompok terdiri dari 4-5 mahasiswa. Masing-masing kelompok kemudian mengidentifikasikan masalah yang dihadapi dalam mendesain media pembelajaran sesuai dengan mata pelajaran yang diberikan. Selanjutnya mahasiswa diminta untuk mampu memecahkan permasalahan yang teridentifikasi.

Tahapan selanjutnya pada tindakan di siklus I ini yaitu pelaksanaan atau creating project. Selama proses pengerjaan proyek media pembelajaran ini, mahasiswa diberikan kesempatan seluas-luasnya dalam merencanakan (planning), membuat (creating), dan mempresentasikan serta mengevaluasi (processing) media pembelajaran yang dihasilkan. Di awal siklus ini mahasiswa terlihat berani mengeluarkan ide dan pendapat terkait pemecahan permasalahan yang dihadapi.
Data hasil observasi kreativitas mahasiswa secara keseluruhan pada siklus I ini menunjukkan peningkatan yaitu menjadi $63,4 \%$. Dimana peningkatan yang terjadi adalah sebanyak 12,2\%. Dari hasil observasi pelaksanaan pembelajaran juga diperoleh hasil bahwa selama proses perkuliahan mahasiswa aktif berdiskusi dan juga aktif mengerjakan, serta terlihat senang. Mahasiswa terlihat bekerjasama dalam pengerjaan proyek media pembelajaran. Hal ini terlihat dengan adanya pembagian kerja pada team work mereka. Selama proses pembelajaran, mahasiswa juga mampu mengeluarkan berbagai ide terkait dengan perancangan media yang akan mereka buat. Di akhir siklus I, pada tahap presentasi dan evaluasi, mahasiswa mampu mempresentasikan kelebihan-kelebihan dari media pembelajaran yang mereka buat. Sedangkan kelompok lain, mampu memberikan kritikan dan saran dalam mengevaluasi produk media pembelajaran yang dihasilkan oleh kelompok lain.

\section{Siklus II}

Tindakan siklus II dilaksanakan mulai dari pertengahan bulan Oktober sampai dengan akhir bulan November (6 kali pertemuan). Jika di siklus I mahasiswa diintruksikan untuk membuat proyek berupa media pembelajaran konvensional, maka di siklus II ini mahasiswa diintruksikan untuk membuat proyek media pembelajaran digital yang berupa video pembelajaran.

Sama seperti pada siklus I, mahasiswa masih berada pada kelompok yang sama dan dihadapkan pada permasalahan ketersediaan media pembelajaran digital di era 4.0. Berbeda dengan proyek sebelumnya, pada proyek kedua ini mahasiswa dituntut untuk menggunakan keahliannya di bidang teknologi untuk dapat menghasilkan produk media pembelajaran digital yang berupa video pembelajaran.

Sebelum membuat video pembelajaran, mahasiswa dibekali pengetahuan dalam bidang videografi maupun photografi. Mahasiswa menganalisis beberapa video tentang teknik dan tips dalam membuat video dengan menggunakan kamera HP, termasuk teknik sudut/angel pengambilan gambar/video, dan teknik memegang HP agar gambar tidak bergoyang dan terlihat smooth.

Untuk menghasilkan video pembelajaran, mahasiswa diberikan kebebasan dalam memilih aplikasi atau software pembuatan video. Mahasiswa juga bebas dalam menentukan tempat pelaksanaan pengambilan video. Peneliti hanya mengarahkan tentang 
unsur-unsur yang harus ada dalam video pembelajaran dan batas durasi video pembelajaran yang dibuat.

Selama proses pembelajaran siklus ke II ini, mahasiswa terlihat aktif berdiskusi, namun terlihat lebih serius dalam pembuatan proyek kelompok. Jika di siklus I mahasiswa masih bisa berdiskusi sembari mengerjakan media pembelajaran, maka pada siklus ke II ini mahasiswa cenderung lebih banyak diam dan serius dalam mengerjakan projek di depan laptop.

Secara bergilir, selama siklus II berlangsung, mahasiswa mengkonsultasikan setiap progress dari video pembelajaran yang mereka buat. Di siklus II ini, mahasiswa juga diberikan kesempatan untuk mempresentasikan video pembelajaran yang mereka buat, serta mengevaluasi video pembelajaran yang dibuat oleh kelompok lain.

Data hasil observasi kreativitas mahasiswa secara keseluruhan pada siklus II ini menunjukkan peningkatan yaitu $74,1 \%$. Dimana peningkatan yang terjadi dari siklus I ke siklus ke II adalah sebanyak 10,7\%. Secara lengkap data hasil observasi kreativitas mahasiswa program studi Pendidikan Guru Sekolah Dasar (PGSD) Fakultas Ilmu Pendidikan Universitas Negeri Makassar tahun akademik 2019-2020 dapat dilihat pada tabel 1 berikut.

Tabel 2. Hasil Observasi Kreativitas Mahasiswa PGSD

\begin{tabular}{cccc}
\hline \multicolumn{1}{c}{ Skor } & Pra Siklus & Siklus I & Siklus II \\
\hline Kelas BC61 & $53,6 \%$ & $64,9 \%$ & $78,2 \%$ \\
Kelas BC62 & $57,1 \%$ & $70,6 \%$ & $80,8 \%$ \\
Kelas M61 & $40,5 \%$ & $54,7 \%$ & $63,3 \%$ \\
\hline \multicolumn{1}{c}{ Rata-rata } & $\mathbf{5 1 , 2 \%}$ & $\mathbf{6 3 , 4 \%}$ & $\mathbf{7 4 , 1 \%}$ \\
\hline
\end{tabular}

Dari data table 1 di atas dapat disimpulkan bahwa penerapan model pembelajaran Project Based Learning (PjBL) mampu meningkatkan kretivitas mahasiswa dalam mendesain media pembelajaran. Hal ini dikarenakan dalam model pembelajaran $\mathrm{PjBL}$, mahasiswa PGSD dituntut untuk aktif, bekerjasama, dan kreatif dalam menciptakan media pembelajaran untuk siswa $\mathrm{SD}$, baik berupa media pembelajaran konvensional maupun media pembelajaran digital berupa video pembelajaran. Dengan penerapan model $\mathrm{PjBL}$ ini mahasiswa dituntut untuk menemukan ide yang dapat memberikan solusi terhadap permasalahan yang berkenaan dengan media pembelajaran di lapangan. Adapun peningkatan kreativitas mahasiswa dapat dilihat pada gambar 3 berikut.

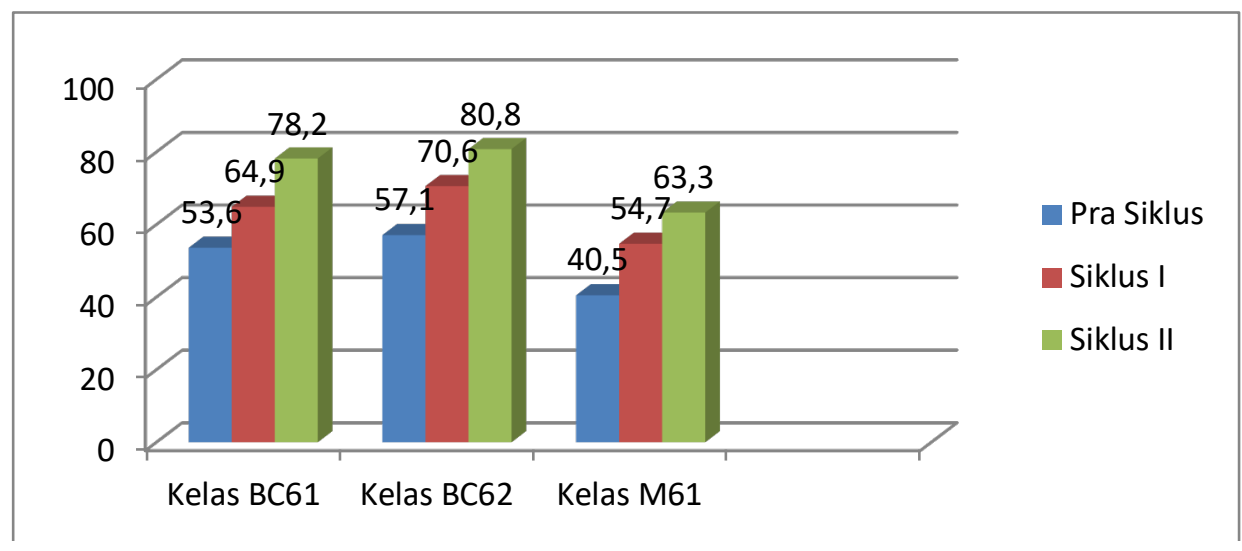

Gambar 3. Grafik Peningkatan Kreativitas Mahasiswa PGSD

Dalam mendesain atau mengembangkan media pembelajaran, harus memperhatikan kualitas. Kualitas media pembelajaran yang dihasilkan oleh mahasiswa program studi Pendidikan Guru Sekolah Dasar (PGSD) Fakultas Ilmu Pendidikan Universitas Negeri Makassar tahun akademik 2019-2020 ini diobservasi oleh 29 observer. Media-media yang dihasilkan, baik media konvensional maupun video pembelajaran dipamerkan dalam acara pameran media Pendidikan Sekolah Dasar yang dilaksanakan pada hari Sabtu, tanggal 15 Februari 2020. Ke-29 observer berkeliling melihat media-media pembelajaran yang dihasilkan mahasiswa PGSD. Kemudian melakukan penilaian dengan mengisi instrumen penilaian kualitas media pembelajaran yang 
telah dipersiapkan, yaitu dengan cara memberikan tanda ceklist.

Dari hasil penilaian kualitas media pembelajaran yang dihasilkan diperoleh data bahwa media pembelajaran yang dihasilkan oleh mahasiswa program studi Pendidikan Guru Sekolah Dasar (PGSD) Fakultas Ilmu Pendidikan Universitas Negeri Makassar tahun akademik 2019-2020 memiliki kualitas yang layak (baik) yaitu dengan nilai rerata 3.34 . Adapun data hasil kualitas media pembelajaran secara keseluruhan, baik media pembelajaran konvensional maupun media pembelajaran digital (video) dapat dilihat pada tabel berikut.

Tabel 3. Data Hasil Kualitas Media Pembelajaran

\begin{tabular}{clcc}
\hline No & \multicolumn{1}{c}{ Komponen } & Rerata & Kategori \\
\hline 1. & Sesuai dengan tujuan yang ingin dicapai; & 3.6 & Sangat layak \\
2. & Praktis, luwes, dan bertahan; & 3.2 & Layak \\
3. & Mampu dan terampil menggunakan, & 3.6 & Sangat layak \\
4. & Keadaan peserta didik, & 3.5 & Sangat layak \\
5. & Ketersediaan. & 2.8 & Cukup \\
\hline \multicolumn{2}{c}{ Rata-rata } \\
\hline
\end{tabular}

\section{KESIMPULAN \& SARAN}

Secara garis besar dapat disimpulkan bahwa penerapan model pembelajaran project based learning (PjBL) merupakan salah satu model pembelajaran yang mampu meningkatkan kreativitas mahasiswa PGSD dalam mendesain media pembelajaran. Hal ini terlihat dari hasil obervasi kreativitas yang ditunjukkan oleh mahasiswa, yaitu pada pra siklus sebesar $51,2 \%$, pada siklus I meningkat menjadi $63,4 \%$, dan pada siklus II meningkat menjadi $74,1 \%$.

Peningkatan kreativitas mahasiswa PGSD dalam mendesain media pembelajaran berhasil karena dengan penerapan model pembelajaran Project Based Learning (PjBL) mahasiswa dituntut untuk memecahkan permasalahan terkait pentingnya mendesain media pembelajaran yang mendukung tercapainya tujuan pembelajaran. Dalam penerapan Project Based Learning (PjBL) ini, mahasiswa terlibat aktif, terlihat senang, mampu bekerjasama dalam tim, serta mampu memberikan ide maupun pendapat selama proses pembelajaran.

Pada siklus I mahasiswa menghasilkan media pembelajaran yang berupa media konvensional. Sedangkan pada siklus II proyek yang dikerjakan mahasiswa yaitu media pembelajaran digital (video). Adapun kualitas media pembelajaran yang dihasilkan mendapakan kategori layak (baik) dengan rerata skor 3,34.

\section{DAFTAR PUSTAKA}

Abdullah, R. (2017). Pembelajaran Dalam Perspektif Kreativitas Guru Dalam Pemanfaatan Media Pembelajaran. Lantanida Journal, 4(1), 35. https://doi.org/10.22373/lj.v4i1.1866
Ardianti, S. D., Pratiwi, I. A., \& Kanzunnudin, M. (2017). Implementasi Project Based Learning (PjBL) Berpendekatan Science Edutainment Terhadap Kreativitas Peserta Didik. Refleksi Edukatika: Jurnal Ilmiah Kependidikan, $\quad 7(2), \quad 145-150$. https://doi.org/10.24176/re.v7i2.1225

Arikunto, Suharsimi. (2014). Penelitian Tindakan Kelas. Jakarta: PT Bumi Aksara.

Azhar Arsyad. (2013). Media Pembelajaran. Jakarta, Rajawali Press.

Divan, S., Baci, R., Nardi, M., Wejang, H. E. A., Sam, A., \& Rofita, D. (2020). Peningkatan Kreativitas Guru dalam Mendesain Kartu menjadi Media Pembelajaran di Sekolah Dasar. Randang Tana: Jurnal Pengabdian Masyarakat, 3(2), 85-92. https://doi.org/https://doi.org/10.36928/jrt .v3i2.386

Fatmawiyati, J. (2018). Telaah Kreativitas. Tersedia (online): https://www.researchgate.net/publication /328217424 (6 Juni 2020). October, 0-21.

Haylock, D. (1997). Recognizing Mathematical Creativity in Schoolchildren, Mathematische Kreativität bei Schulkindern erkennen. ZDM Mathematics Education Journal, 29, 6874.

https://doi.org/https://doi.org/10.1007/s11 858-997-0002-y

Hotimah, H., \& Muhtadi, A. (2017). PENGEMBANGAN MULTIMEDIA PEMBELAJARAN INTERAKTIF IPA UNTUK MENINGKATKAN PEMAHAMAN SISWA PADA MATERI 
MIKROORGANISME SMP. Jurnal Inovasi Teknologi Pendidikan, 4(2), 201213.

http://journal.uny.ac.id/index.php/jitp

Hopkins, David (2008). A Teacher's Guide to Classroom Research Fourth edition. Philadephia: Open University Press.

Kusumah, W dan Dwitagama, D. (2010). Mengenal Penelitian Tindakan Kelas. Jakarta: PT. Indeks.

Kaufman, J. C., \& Sternberg, R. J. (2011). The Cambridge handbook of creativity. In Choice Reviews Online (Vol. 48, Issue 09). https://doi.org/10.5860/choice.485383

Mahmudi, A. (2008). Tinjauan Kreativitas dalam Pembelajaran Matematika. Tinjauan Kreativitas Dalam Pembelajaran Matematika, 4(2), 37-49. https://doi.org/10.21831/pg.v4i2.559

Munandar, S. C. U. (1997). Inisiatif Dan Kreativitas Anak. Psikologika, 2.

Nakin, J. B. . (2003). Ceativity and Divergent Thinking in Geometry Education. Disertasi University of South Africa. [Online]. https://core.ac.uk/download/pdf/4316473 6.pdf

Purwanto, B. (2011). Pentingnya Kreativitas Guru dan Calon Guru Fisika SMA Dalam Upaya Pengembangan dan Pengadaan Alat Demonstrasi/Eksperimen Untuk Menjelaskan Konsep Dasar Fisika. Prosiding Seminar Nasional Penelitian, Pendidikan Dan Penerapan MIPA, 1 , 229-238.

Rohani. (2017). Meningkatkan Kreativitas Anak Usia Dini melalui Media Bahan Bekas. Raudhah, 05(2), 137. https://doi.org/10.30870/jpppaud.v4i2.46 53

Sugiyono. (2010). Metode Penelitian Pendidikan (Pendekatan Kuantitatif, Kualitatif, $R \quad \& \quad D)$. Bandung: ALFABETA

Sulipan. (2008). Penelitian Tindakan Kelas (Classroom Action Research). Bandung: Widyaiswara.

Titu, M. A. (2015). Penerapan Model Pembelajaran Project Based Learning (PjBL) untuk Meningkatkan Kreativitas Siswa pada Materi Konsepmasalah Ekonomi. Prosiding Seminar Nasional, 176-186. 